\title{
Polar organic marker compounds in atmospheric aerosols during the LBA-SMOCC 2002 biomass burning experiment in Rondônia, Brazil: sources and source processes, time series, diel variations and size distributions
}

\author{
M. Claeys ${ }^{1}$, I. Kourtchev ${ }^{1, *}$, V. Pashynska ${ }^{1, * *}$, G. Vas $^{1,{ }^{* * *}}$, R. Vermeylen ${ }^{1}$, W. Wang ${ }^{1}$, J. Cafmeyer ${ }^{2}$, X. Chi ${ }^{2}$, \\ P. Artaxo ${ }^{3}$, M. O. Andreae ${ }^{4}$, and W. Maenhaut ${ }^{2}$ \\ ${ }^{1}$ Department of Pharmaceutical Sciences, University of Antwerp (Campus Drie Eiken), Antwerp, Belgium \\ ${ }^{2}$ Department of Analytical Chemistry, Institute for Nuclear Sciences, Ghent University, Gent, Belgium \\ ${ }^{3}$ Institute of Physics, University of São Paulo, São Paulo, Brazil \\ ${ }^{4}$ Biogeochemistry Department, Max Planck Institute for Chemistry, Mainz, Germany \\ * present address: Institute for Reference Materials and Measurements (IRMM), European Commission, Joint Research \\ Centre, Geel, Belgium \\ ${ }^{* *}$ present address: B. Verkin Institute for Low Temperature Physics and Engineering, National Academy of Sciences of \\ Ukraine, Kharkov, Ukraine \\ *** present address: Cordis Corporation, Analytical Technology, Spring House, PA, USA
}

Received: 7 April 2010 - Published in Atmos. Chem. Phys. Discuss.: 23 April 2010

Revised: 11 September 2010 - Accepted: 21 September 2010 - Published: 5 October 2010

\begin{abstract}
Measurements of polar organic marker compounds were performed on aerosols that were collected at a pasture site in the Amazon basin (Rondônia, Brazil) using a high-volume dichotomous sampler (HVDS) and a Micro-Orifice Uniform Deposit Impactor (MOUDI) within the framework of the 2002 LBA-SMOCC (Large-Scale Biosphere Atmosphere Experiment in Amazônia - Smoke Aerosols, Clouds, Rainfall, and Climate: Aerosols From Biomass Burning Perturb Global and Regional Climate) campaign. The campaign spanned the late dry season (biomass burning), a transition period, and the onset of the wet season (clean conditions). In the present study a more detailed discussion is presented compared to previous reports on the behavior of selected polar marker compounds, including levoglucosan, malic acid, isoprene secondary organic aerosol (SOA) tracers and tracers for fungal spores. The tracer data are discussed taking into account new insights that recently became available into their stability and/or aerosol formation processes. During all three periods, levoglucosan was the most dominant identified organic species in the
\end{abstract}

Correspondence to: M. Claeys (magda.claeys@ua.ac.be)
$\mathrm{PM}_{2.5}$ size fraction of the HVDS samples. In the dry period levoglucosan reached concentrations of up to $7.5 \mu \mathrm{g} \mathrm{m}^{-3}$ and exhibited diel variations with a nighttime prevalence. It was closely associated with the PM mass in the size-segregated samples and was mainly present in the fine mode, except during the wet period where it peaked in the coarse mode. Isoprene SOA tracers showed an average concentration of $250 \mathrm{ng} \mathrm{m}^{-3}$ during the dry period versus $157 \mathrm{ng} \mathrm{m}^{-3}$ during the transition period and $52 \mathrm{ng} \mathrm{m}^{-3}$ during the wet period. Malic acid and the 2-methyltetrols exhibited a different size distribution pattern, which is consistent with different aerosol formation processes (i.e., gas-to-particle partitioning in the case of malic acid and heterogeneous formation from gasphase precursors in the case of the 2-methyltetrols). The 2-methyltetrols were mainly associated with the fine mode during all periods, while malic acid was prevalent in the fine mode only during the dry and transition periods, and dominant in the coarse mode during the wet period. The sum of the fungal spore tracers arabitol, mannitol, and erythritol in the $\mathrm{PM}_{2.5}$ fraction of the HVDS samples during the dry, transition, and wet periods was, on average, $54 \mathrm{ng} \mathrm{m}^{-3}$, $34 \mathrm{ng} \mathrm{m}^{-3}$, and $27 \mathrm{ng} \mathrm{m}^{-3}$, respectively, and revealed minor day/night variation. The mass size distributions of arabitol and mannitol during all periods showed similar patterns and

Published by Copernicus Publications on behalf of the European Geosciences Union. 
an association with the coarse mode, consistent with their primary origin. The results show that even under the heavy smoke conditions of the dry period a natural background with contributions from bioaerosols and isoprene SOA can be revealed. The enhancement in isoprene SOA in the dry season is mainly attributed to an increased acidity of the aerosols, increased $\mathrm{NO}_{\mathrm{x}}$ concentrations and a decreased wet deposition.

\section{Introduction}

The Amazon basin is a region where widespread biomass burning takes place during the dry season which significantly alters the chemical properties of the tropical pristine background atmosphere. The carbonaceous aerosol over the Amazon basin has been intensively studied during recent years since it contains a large fraction of water-soluble organic carbon (WSOC). The latter fraction is of climatic relevance since it enhances the ability of the aerosol to act as cloud condensation nuclei (e.g., Novakov and Penner, 1993; Novakov and Corrigan, 1996; Mochida and Kawamura, 2004) and may as such affect cloud processes (e.g., Shulman et al., 1996; Facchini et al., 1999; Roberts et al., 2002; Mircea et al., 2005). As to chemical composition studies of the Amazonian carbonaceous aerosol, emphasis has been formerly placed on the measurement and/or characterization of individual compounds that are hygroscopic and/or can serve as tracers for aerosol sources and/or processes, i.e., anhydrosugars, sugars, 2-methyltetrols, polyols, hydroxyacids, dicarboxylic acids, and phenolic acids (Kubátová et al., 2000; Zdráhal et al., 2002; Graham et al., 2002, 2003; Claeys et al., 2004; Falkovich et al., 2005; Schkolnik et al., 2005), as well as of humic-like substances (HULIS) that represent a large fraction of the WSOC (Mayol-Bracero et al., 2002).

The major anhydrosugar detected in the aerosol samples is levoglucosan (1,6-anhydro- $\beta$-D-glucopyranose), which is formed through pyrolysis of cellulose, the main building material of wood, at temperatures higher than $300^{\circ} \mathrm{C}$ (Shafizadeh, 1982). It is accompanied by minor stereoisomers, including 1,6-anhydro- $\beta$-D-glucofuranose, mannosan (1,6-anhydro- $\beta$-D-mannopyranose), and galactosan (1,6anhydro- $\beta$-D-galactopyranose), all resulting from the pyrolysis of hemicelluloses present in wood. Levoglucosan is a well-established tracer for pyrolysis of cellulose in biomass smoke (Simoneit et al., 1999; Nolte et al., 2001; Simoneit, 2002) and has been extensively used to monitor biomass smoke in the Amazon basin (Zdráhal et al., 2002; Graham et al., 2002, 2003; Schkolnik et al., 2005) and in other tropical and subtropical areas where biomass burning takes place such as, for example, southern Africa (Gao et al., 2003). Levoglucosan has for a long time thought to be fairly inert; however, recent laboratory studies show that it decays upon a time scale relevant to particle lifetimes by heterogeneous $\mathrm{OH}$ radical-initiated oxidation (Hoffmann et al., 2010; Hennigan et al., 2010). Sugars present in atmospheric aerosol comprise the monosaccharides, glucose and fructose, and the disaccharides, sucrose and trehalose. Glucose, fructose, and sucrose originate from plant material such as pollen, fruits, and their fragments (Bartolozzi et al., 1997; Baker et al., 1998; Pacini, 2000; Yttri et al., 2007), but in addition glucose may also result from cellulose pyrolysis (Shafizadeh, 1982), while trehalose is due to fungal spores (Lewis and Smith, 1967; Bieleski, 1982). The sugar alcohols, arabitol, mannitol, and erythritol, which are denoted by polyols, are marker compounds for fungal spores (Lewis and Smith, 1967; Bieleski, 1982).

The 2-methyltetrols (2-methylthreitol and 2methylerythritol) and the $\mathrm{C}_{5}$-alkene triols [2-methyl1,3,4-trihydroxy-1-butene (cis and trans) and 3-methyl2,3,4-trihydroxy-1-butene] have first been identified in Amazonian aerosols (Claeys et al., 2004; Wang et al., 2005) and were, based on their $\mathrm{C}_{5}$-isoprene skeleton, proposed to be photooxidation products of isoprene. In subsequent laboratory (smog chamber) experiments it was confirmed that the 2-methyltetrols are formed through photooxidation of isoprene under varying $\mathrm{NO}_{\mathrm{x}}$ regimes (Edney et al., 2005; Böge et al., 2006; Surratt et al., 2006, 2010; Sato, 2008), while the $\mathrm{C}_{5}$-alkene triols could only be detected in the absence of $\mathrm{NO}_{\mathrm{x}}$ (Surratt et al., 2006, 2010; Kleindienst et al., 2009). Dicarboxylic acids and hydroxycarboxylic acids comprise a very large group of compounds; a major hydroxycarboxylic acid is malic acid, which can be regarded as intermediate in the oxidation of $\mathrm{C}_{n}(n \leq 6)$ semivolatile carboxylic acids (which are also oxidation products of unsaturated fatty acids) and is believed to be formed through further photooxidation of succinic acid (Kawamura and Gagosian, 1990; Kawamura and Ikushima, 1993). Dicarboxylic acids are known to have many sources, both anthropogenic and biogenic ones (Rogge et al., 1993; Limbeck and Puxbaum, 1999). A recent study examined the molecular profiles of dicarboxylic acids $\left(\mathrm{C}_{2}-\mathrm{C}_{11}\right)$ and related compounds (ketocarboxylic acids and dicarbonyls) in $\mathrm{PM}_{2.5}$ samples from the intensive biomass burning period of the LBA-SMOCC 2002 campaign and found higher ratios of the latter compounds to biomass burning tracers (i.e., levoglucosan, $\mathrm{K}^{+}$) during daytime, suggesting the importance of photochemical production (Kundu et al., 2010).

In the present study, we focus on major polar organic marker compounds and discuss their time series, diel variations, mass size distributions, and aerosol formation processes. The major polar organic marker compounds include: (a) levoglucosan, (b) malic acid, (c) photooxidation products of isoprene, i.e., 2-methyltetrols and $\mathrm{C}_{5}$-alkene triols, and (d) polyols (arabitol, mannitol, and erythritol). The latter compounds were selected for two reasons: (a) they correspond to major single compounds that can be detected in the fine $\left(\mathrm{PM}_{2.5}\right)$ size fraction of high-volume dichotomous samples 
by gas chromatography/mass spectrometry (GC/MS) with prior trimethylsilylation in the full scan mode, and (b) they provide important information on aerosol sources and source processes. Part of the presented data have been reported by Decesari et al. (2006) on the overall composition of the carbonaceous aerosol in Rondônia during the LBA-SMOCC campaign and its representation through model compounds, and by Fuzzi et al. (2007) on the inorganic and organic composition of the corresponding size-segregated aerosol; these earlier presented data are included here to allow a more detailed and coherent discussion on time series, diel variations, and size distributions of major polar organic marker compounds.

\section{Experimental}

\subsection{Site description}

Ground-based measurements were performed as part of the LBA-SMOCC campaign from 9 September till 14 November 2002 (66 days) at a pasture site (Fazenda Nossa Senhora Aparecida, $10^{\circ} 04^{\prime} 44^{\prime \prime} \mathrm{S}, 62^{\circ} 21^{\prime} 27^{\prime \prime} \mathrm{W}, 315 \mathrm{~m}$ a.s.l.). This site is located within Rondônia, Brazil, a region where extensive deforestation took place in recent years. The campaign covered a dry period ( 9 September -8 October), corresponding to the end of the dry season (biomass burning season), a transition period (8-30 October), and a wet period (30 October-14 November), corresponding to the beginning of the wet season. For a more detailed description of the sampling site, see Andreae et al. (2002). For an overview of the meteorological conditions, including temperature, during the campaign, see Fuzzi et al. (2007). The temperature showed little variability during the period considered, with monthly mean values around $25.0^{\circ} \mathrm{C}$, although there was a variation in the daily maximum temperature span: $10.7^{\circ} \mathrm{C}$ in September, $9.4^{\circ} \mathrm{C}$ in October and $8.0^{\circ} \mathrm{C}$ in November. During the dry season, and, to a lesser extent, the transition period, widespread fire activity was observed in Rondônia and Mato Grosso, as well as in other states along the southern and south eastern margin of the Amazon forest. Conversely, biomass burning was substantially reduced at the beginning of November after the onset of persistent wet conditions (Andreae et al., 2004).

\subsection{Aerosol sampling}

A high-volume dichotomous virtual sampler (HVDS), located $2 \mathrm{~m}$ above ground level, was used to collect samples in two size fractions, a fine $[<2.5 \mu \mathrm{m}$ aerodynamic diameter (AD)] and a coarse $(>2.5 \mu \mathrm{m}$ AD) fraction (Solomon et al., 1983). Double Pallflex quartz fiber filters (of $102 \mathrm{~mm}$ diameter), which had been pre-fired at $550{ }^{\circ} \mathrm{C}$ to remove organic contaminants, were used to collect each of the two size fractions. For collection of size-fractionated aerosol samples, a ten-stage Micro-Orifice Uniform Deposit Impactor (MOUDI), with 50\% aerodynamic cutoff diameters for the pre-impaction stage (stage 0 ) and 10 regular stages of 18, 9.9, $6.2,3.1,1.8,1.0,0.603,0.301,0.164,0.094$, and $0.053 \mu \mathrm{m}$, was employed. Aluminum foils of $37 \mathrm{~mm}$ diameter (pre-fired at $550^{\circ} \mathrm{C}$ ) were used as collection substrates in the MOUDI. Separate day- and nighttime samples were collected during most days of the dry period and part of the transition period. During the rest of the transition period, the collection time was $24 \mathrm{~h}$, whereas during the wet period, day- and nighttime samples were collected for $48 \mathrm{~h}$. A total of 80 HVDS samples and 80 MOUDI sample sets were collected.

$\mathrm{PM}_{2}$ mass data were derived from the fine $(<2 \mu \mathrm{m} \mathrm{AD})$ size fraction of a Gent $\mathrm{PM}_{10}$ stacked filter unit (SFU) sampler that was operated in parallel. A Pall Teflo filter was used as fine filter in the SFU sampler.

\subsection{Aerosol analysis}

PM mass data were obtained by weighing the SFU filters and the MOUDI aluminum foils before and after sampling with a microbalance of $1 \mu \mathrm{g}$ sensitivity. The weighings were done at $20^{\circ} \mathrm{C}$ and $50 \%$ relative humidity (RH) and the filters were equilibrated at these conditions for $24 \mathrm{~h}$ prior to weighing. All filters of the HVDS samples were analyzed for organic carbon (OC) and elemental carbon (EC) by a thermaloptical (TOT) technique (Birch and Cary, 1996) and the fine size fraction filters also for WSOC as described by Viana et al. (2006).

Selected polar organic marker compounds in the front fine filters of all HVDS quartz fiber filter samples and in the aluminum foils of selected MOUDI samples were quantified using GC/MS techniques that incorporated a derivatization step in order to convert carboxylic and hydroxyl groups to trimethylsilylated ester and ether derivatives, respectively. The method was targeted to the quantitation of sugar-like compounds, including anhydrosugars (levoglucosan, mannosan, galactosan, and 1,6-anhydro- $\beta$ D-glucofuranose), 2-methyltetrols (2-methylthreitol and 2methylerythritol), monosaccharides (fructose and glucose), and polyols (erythritol, arabitol, and mannitol). The analytical procedure was adapted from a method previously described and validated for the determination of levoglucosan in urban aerosols (Pashynska et al., 2002). In addition to the above mentioned sugar-like compounds, malic acid was also measured with the same method; however, more accurate data for malic acid were obtained with a method targeted to the analysis of polar hydroxycarboxylic acids, as has been reported in a previous study (Decesari et al., 2006). The malic acid data used in the present study for the fine HVDS samples were, therefore, obtained with the latter method (method 2 of the cited study). In addition, succinic acid data obtained with the latter method were also used for the detailed interpretation of the malic acid data.

A part of the front quartz filter sample (1/16 or $1 / 32)$ or of the aluminum foil (1/2 or $1 / 4)$ was used for extraction. Before extraction, the recovery standards, 
methyl- $\beta$-L-xylanopyranoside and deuterated $\left(D_{3}\right)$ malic acid (2,2,3- $D_{3}$-malic acid; Cambridge Isotope Laboratories, Andover, MA, USA) were added. Briefly, the sample work-up procedure consisted of extraction with 3 times $20 \mathrm{~mL}$ dichloromethane:methanol $(4: 1, v / v)$ and derivatization of the residues into trimethylsilylether derivatives with $50 \mu \mathrm{L}$ of a 3:5 $(\mathrm{v} / \mathrm{v})$ mixture of pyridine and $N$-methyl$N$-trimethylsilyltrifluoroacetamide (MSTFA) containing 1\% trimethylchlorosilane (TMCS) (Pierce, Rockford, IL, USA). GC/MS analysis was performed with a TRACE GC2000 gas chromatograph and a Polaris $\mathrm{Q}$ ion trap mass spectrometer equipped with a CP Sil 8CB low-bleed capillary column (95\% dimethyl-, 5\% phenylpolysiloxane, $0.25 \mu \mathrm{m}$ film thickness, $30 \mathrm{~m} \times 0.25 \mathrm{~mm}$ i.d.; Chrompack, Middelburg, The Netherlands), which was preceded by a deactivated silica precolumn $(2 \mathrm{~m} \times 0.25 \mathrm{~mm}$ i.d. $)$. The following temperature program was applied: the initial temperature was $50^{\circ} \mathrm{C}$ and kept for $5 \mathrm{~min}$, the temperature was then increased to $200^{\circ} \mathrm{C}$ at the rate of $3^{\circ} \mathrm{C} \mathrm{min}^{-1}$ and kept at that temperature for a further $2 \mathrm{~min}$ and then raised to $310^{\circ} \mathrm{C}$ at the rate of $30^{\circ} \mathrm{C} \mathrm{min}^{-1}$; the total analysis time was $62 \mathrm{~min}$. For the analysis of the HVDS samples, the GC/MS instrument was operated in the electron ionization and the full scan modes (mass range $\mathrm{m} / \mathrm{z} 45-500$ ), and quantification was based on mass chromatographic data (i.e., extracted ion chromatograms), while for the analysis of the MOUDI samples, the instrument was operated in the selected ion monitoring mode (instead of the full scan mode) with an ion dwell time of $25 \mathrm{~ms}$. The selected ions were at $m / z, 204$ and 217 for the internal recovery standard (IS), methyl- $\beta$-D-xylanopyranoside, and for levoglucosan, $\mathrm{m} / \mathrm{z}$ 219 and 277 for the 2-methyltetrols (2-methylthreitol and 2methylerythritol), $\mathrm{m} / z 233$ and 307 for malic acid, $\mathrm{m} / \mathrm{z} 236$ and 310 for deuterated $\left(D_{3}\right)$ malic acid, $\mathrm{m} / z 217$ and 319 for arabitol and mannitol, and $m / z 231$ for the alkene triol derivatives of isoprene (2-methyl-1,3,4-trihydroxy-1-butene (cis and trans) and 3-methyl-2,3,4-trihydroxy-1-butene). For derivatization of standard solutions of all saccharidic compounds, the same procedure as that used for the aerosol extracts was applied. The quantification of the monosaccharide anhydrides (levoglucosan, mannosan, and galactosan), the polyols (arabitol, mannitol, and erythritol), the monosaccharides (fructose and glucose), and the 2-methyltetrols was based on an internal standard calibration procedure employing methyl- $\beta$-L-xylanopyranoside as internal recovery standard and pure reference compounds, if available. For assessing the amounts of the 2-methyltetrols and $\mathrm{C}_{5}$-alkene triols, for which no pure reference compounds were available, the response factor of erythritol was used, while for assessing the amount of malic acid, the response factor of deuterated $\left(D_{3}\right)$ malic acid was used. Duplicate analyses showed that the precision of the determinations was about $10 \%$. All reported concentrations were corrected for procedural blanks.

\section{Results and discussion}

\subsection{GC/MS chromatograms}

Figure 1 presents a typical total ion chromatogram (TIC) obtained for a trimethylsilylated extract of a fine daytime HVDS filter sample collected during the transition period (26-27 October). The chromatogram is dominated by levoglucosan and smaller peaks are clearly observed for malic acid, the 2-methyltetrols, the $\mathrm{C}_{5}$-alkene triols, and anhydrosugars that are isomeric to levoglucosan (mannosan and 1,6 -anhydro- $\beta$-D-glucofuranose). It is worth noting that the latter compounds can be detected in the TIC so that more selective detection, i.e., mass chromatographic or selected ion monitoring detection, was not necessary. However, in the present study, mass chromatography using specific ions was utilized to obtain more clear chromatographic peaks for less abundant compounds, i.e., polyols (arabitol, mannitol, and erythritol), and, in most cases, $\mathrm{C}_{5}$-alkene triols (2-methyl-1,3,4-trihydroxy-1-butene (cis and trans) and 3methyl-2,3,4-trihydroxy-1-butene), while selected ion monitoring was performed for the analysis of aluminum foils collected with the MOUDI, where the amounts found on the different stages are much lower than on the HVDS filter samples.

\subsection{Time series, diurnal variations and size distributions}

\subsubsection{PM, OC, EC, and levoglucosan}

Table 1 summarizes median and mean concentrations and concentration ranges for OC, EC, WSOC, and the selected organic species in the fine size fraction of the HVDS filter samples for the dry, transition, and wet periods of the LBASMOCC 2002 campaign. In addition, Table 1 presents mean percentages of the fine $\mathrm{OC}$ that is attributable to the carbon in the organic compounds. Figure 2 shows the time series for fine PM $\left(\mathrm{PM}_{2}\right)$, and $\mathrm{OC}, \mathrm{EC}$, and levoglucosan for the fine size fraction of the HVDS samples. It can be seen that all four parameters show substantial variation throughout the campaign and are fairly well correlated with each other. The correlations between the PM $\left(\mathrm{PM}_{2}\right)$ and $\mathrm{OC}, \mathrm{EC}$, and levoglucosan for the dry period were $0.83,0.84$, and 0.75 , respectively. During the dry period, which is characterized by intense deforestation fires, high $\mathrm{PM}_{2.5}$ levels of levoglucosan are measured (mean value $2.1 \mu \mathrm{g} \mathrm{m}^{-3}$ ), while during the transition and wet periods, the mean levels decrease to $0.40 \mu \mathrm{g} \mathrm{m}^{-3}$ and $0.06 \mu \mathrm{g} \mathrm{m}^{-3}$, respectively. It can also be seen in Fig. 2 that diel differences are observed for the fine $\mathrm{PM}\left(\mathrm{PM}_{2}\right), \mathrm{OC}, \mathrm{EC}$, and levoglucosan during the dry period when separate day- and nighttime sampling was carried out and that the highest concentrations are found at night. The higher nighttime concentrations can be partly explained by trapping of the pyrogenic aerosol under the shallow nocturnal 
Table 1. Median and mean concentrations and concentration ranges for OC, EC, WSOC, and selected organic species (and mean percentages of the OC attributable to the carbon in the organic compounds) in the front filters of the fine size fraction of the HVDS filter samples for the dry, transition, and wet periods of the LBA-SMOCC 2002 campaign.

\begin{tabular}{|c|c|c|c|c|c|c|c|c|c|c|c|c|}
\hline \multirow[t]{3}{*}{ Species } & \multicolumn{4}{|c|}{ Dry period $(N=53)$} & \multicolumn{4}{|c|}{ Transition period $(N=20)$} & \multicolumn{4}{|c|}{ Wet period $(N=7)$} \\
\hline & \multicolumn{3}{|c|}{ Conc., $\operatorname{ng~m}^{-3}\left(* \mu \mathrm{g} \mathrm{m}^{-3}\right)$} & \multirow{2}{*}{$\begin{array}{l}\text { Mean } \\
\% \text { OC }\end{array}$} & \multicolumn{3}{|c|}{ Conc., $\mathrm{ng} \mathrm{m}^{-3}\left(* \mu \mathrm{g} \mathrm{m}^{-3}\right)$} & \multirow{2}{*}{$\begin{array}{l}\text { Mean } \\
\% \text { OC }\end{array}$} & \multicolumn{3}{|c|}{ Conc., $\mathrm{ng} \mathrm{m}^{-3}\left(* \mu \mathrm{g} \mathrm{m}^{-3}\right)$} & \multirow{2}{*}{$\begin{array}{l}\text { Mean } \\
\% \text { OC }\end{array}$} \\
\hline & Median & Mean & Range & & Median & Mean & Range & & Median & Mean & Range & \\
\hline OC* & 27 & 32 & $4.1-79$ & $\mathrm{n} / \mathrm{a}$ & 8.4 & 9.1 & $3.9-15.7$ & $\mathrm{n} / \mathrm{a}$ & 1.80 & 1.60 & $0.93-2.3$ & $\mathrm{n} / \mathrm{a}$ \\
\hline EC* & 0.98 & 1.11 & $0.30-2.4$ & $\mathrm{n} / \mathrm{a}$ & 0.42 & 0.42 & $0.18-0.66$ & $\mathrm{n} / \mathrm{a}$ & 0.07 & 0.09 & $0.04-0.18$ & $\mathrm{n} / \mathrm{a}$ \\
\hline WSOC* & 17.5 & 21 & $2.6-53$ & 66 & 6.0 & 6.6 & $2.5-10.5$ & 73 & 0.98 & 1.04 & $0.65-1.92$ & 64 \\
\hline levoglucosan & 1380 & 2100 & $126-7500$ & 2.63 & 350 & 400 & $106-1860$ & 1.91 & 26 & 58 & $15.7-150$ & 1.46 \\
\hline mannosan & 88 & 148 & $10.1-540$ & 0.18 & 27 & 31 & $7.3-70$ & 0.15 & 2.8 & 4.1 & $1.9-7.4$ & 0.11 \\
\hline galactosan & 26 & 57 & $4.3-260$ & 0.07 & 10.1 & 11.4 & $2.8-32$ & 0.05 & 0.9 & 1.1 & $<0.5-2.4$ & 0.03 \\
\hline arabitol & 14.7 & 16.8 & $<2.0-41$ & 0.03 & 9.8 & 9.8 & $4.5-22$ & 0.05 & 8.2 & 8.7 & $5.3-11.8$ & 0.27 \\
\hline mannitol & 19.4 & 23 & $3.9-52$ & 0.05 & 8.3 & 20 & $9.5-47$ & 0.10 & 19.2 & 17.7 & $11.1-20$ & 0.50 \\
\hline erythritol & 12.8 & 14.4 & $2.3-37$ & 0.02 & 4.1 & 4.4 & $1.6-8.0$ & 0.02 & 1.1 & 1.0 & $0.7-1.3$ & 0.03 \\
\hline glucose & 47 & 52 & $15.1-130$ & 0.09 & 34 & 34 & $16.6-53$ & 0.17 & 27 & 27 & $16.3-37$ & 0.74 \\
\hline fructose & 13.9 & 15.2 & $<2.0-44$ & 0.03 & 8.5 & 8.0 & $2.5-13.2$ & 0.04 & 4.8 & 5.1 & $1.2-12.5$ & 0.14 \\
\hline 2-methylthreitol & 51 & 52 & $4.8-98$ & 0.09 & 19.0 & 26 & $7.6-89$ & 0.13 & 8.2 & 9.1 & $3.0-20$ & 0.26 \\
\hline 2-methylerythritol & 145 & 143 & $13.7-320$ & 0.25 & 68 & 94 & $22-310$ & 0.48 & 29 & 34 & $13.3-66$ & 1.00 \\
\hline $\mathrm{C}_{5}$-alkene triols & 42 & 54 & $5.3-164$ & 0.11 & 29 & 37 & 9.9-93 & 0.22 & 6.3 & 8.7 & $4.3-16.0$ & 0.29 \\
\hline malic acid & 390 & 400 & $138-860$ & 0.57 & 260 & 270 & $163-410$ & 1.15 & 74 & 76 & $37-110$ & 1.69 \\
\hline succinic acid & 500 & 640 & $53-2200$ & 0.83 & 270 & 280 & $100-610$ & 1.23 & 26 & 28 & $8.5-48$ & 0.69 \\
\hline
\end{tabular}

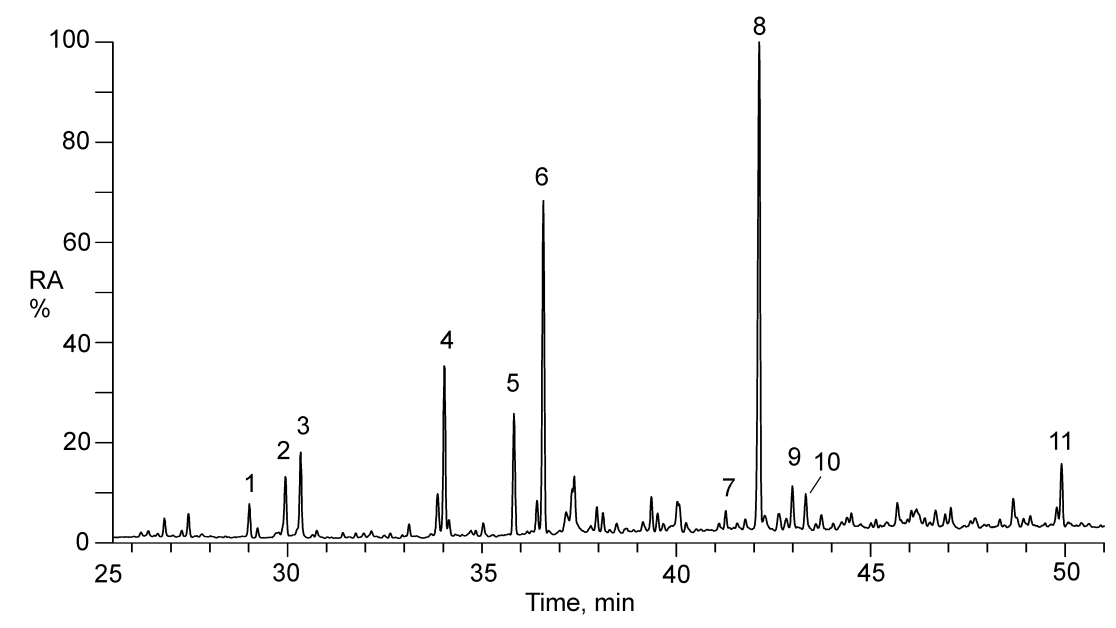

Fig. 1. GC/MS total ion chromatogram (TIC) obtained for a fine daytime HVDS filter sample collected during the transition period (2627 October). (1) cis-2-methyl-1,3,4-trihydroxy-1-butene; (2) 3-methyl-2,3,4-trihydroxy-1-butene; (3) trans-2-methyl-1,3,4-trihydroxy-1butene; (4) malic acid; (5) 2-methylerythritol; (6) 2-methylthreitol; (7) mannosan; (8) levoglucosan; (9) 1,6-anhydro- $\beta$-D-glucofuranose; (10) arabitol; and (11) mannitol.

boundary layer. This concentration effect is due to evolution of the boundary layer, which is much thinner at night, as a result of decreased vertical mixing and dilution (Fish et al., 2004; Rissler et al., 2006). An additional explanation for the higher nighttime concentrations of levoglucosan is photochemical degradation during daytime. In this respect, it has recently been shown that levoglucosan decays upon a time-scale relevant to particle lifetimes by heterogeneous $\mathrm{OH}$ radical-initiated oxidation (Hoffmann et al., 2010; Hennigan et al., 2010).
Figure 3 shows levoglucosan carbon as a percentage of the OC. It is clear that levoglucosan contributes more to the OC during the night, on average $3.1 \pm 0.9 \%$ at night versus $1.8 \pm 0.7 \%$ during the daytime. This diel variation can be explained by a different combustion stage with flaming combustion taking place during daytime when fires are started and smoldering combustion resulting in a less complete oxidation of biomass dominating at night, as has been discussed in more detail by Schkolnik et al. (2005). Our results can also be compared with those of Gao et al. (2003) 


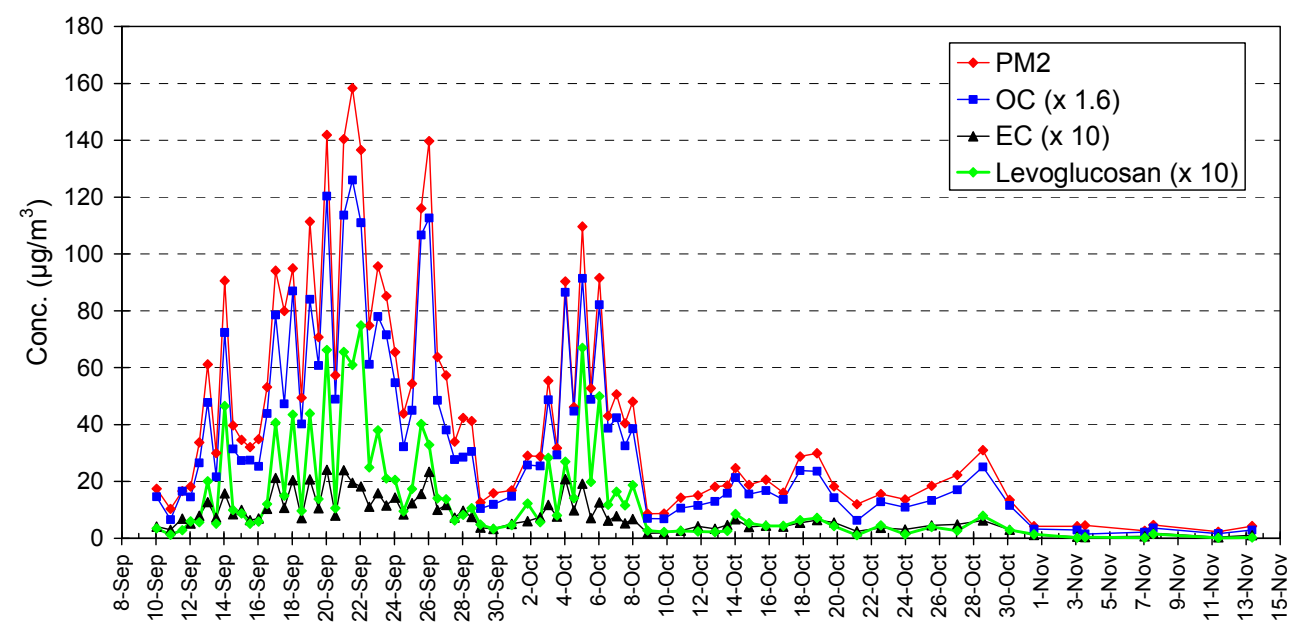

Fig. 2. Time series for fine PM $\left(\mathrm{PM}_{2}\right)$, and for OC, EC, and levoglucosan in the fine filters of the HVDS samples.

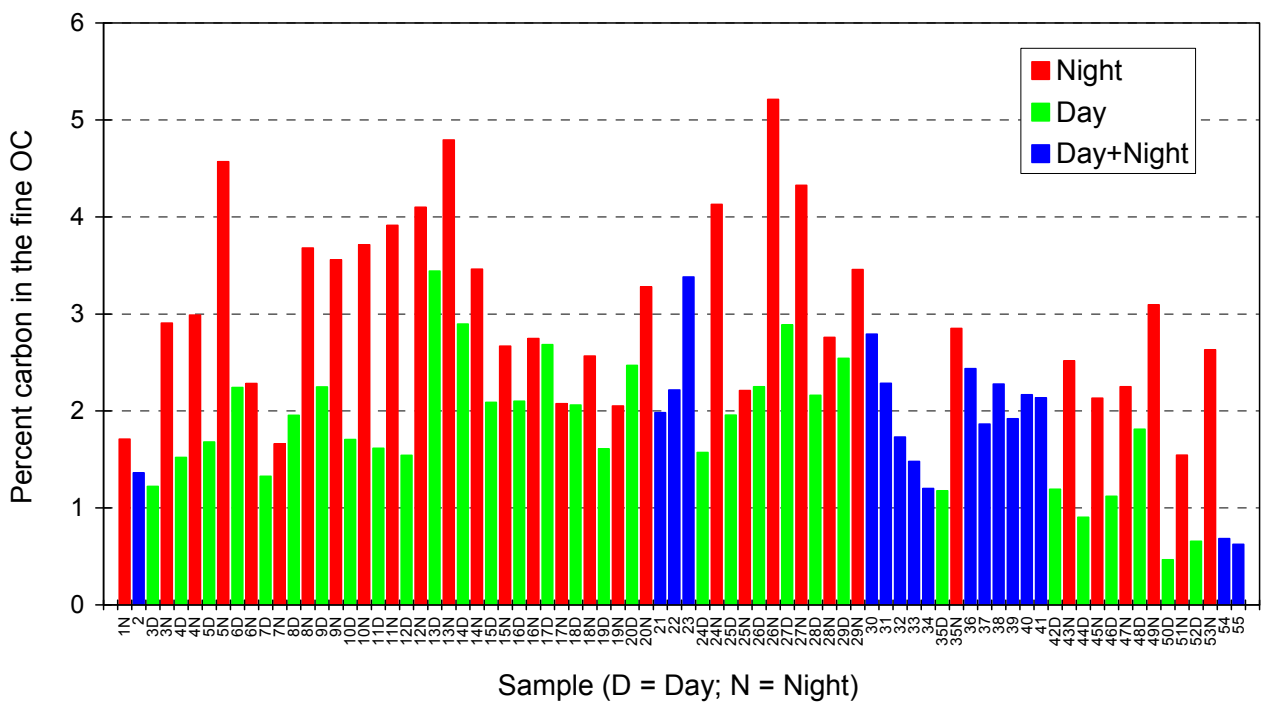

Fig. 3. Time series for the levoglucosan carbon as percent of the fine OC in the HVDS samples. Samples $1 \mathrm{~N}$ through $29 \mathrm{~N}$ are from the dry period, 30 through 48D from the transition period, and 49N through 55 from the wet period.

for smoke aerosol from the SAFARI 2000 experiment in southern Africa, which showed that certain organic species including levoglucosan are more enriched in smoke aerosol from the smoldering than the flaming phase. In addition, the diel variation of levoglucosan can to some extent also be explained by photochemical degradation of levoglucosan during daytime (Hoffmann et al., 2010; Hennigan et al., 2010). However, the data obtained within this field study do not allow to determine which of the two processes, i.e., the combustion stage or the photochemical degradation of levoglucosan during daytime, govern the atmospheric concentrations of levoglucosan, since flaming combustion which is prevalent during daytime is in itself a highly oxidative process. We also examined the diel variation of levoglucosan by expressing its carbon as a percentage of the water-insoluble
$\mathrm{OC}(\mathrm{WIOC}=\mathrm{OC}-\mathrm{WSOC})$, which can be considered as a rough proxy for non-SOA OC. Following this procedure, we see that levoglucosan carbon (be it that it is itself watersoluble) represents only a slightly larger percentage of the WIOC fraction during night than during the day, i.e., on average $8.6 \pm 2.1 \%$ at night versus $6.4 \pm 2.6 \%$ during the daytime. This night/day difference is (in relative terms; the ratio between the two percentages is 1.34) substantially smaller than that found for the difference in the percentage of levoglucosan carbon to the $\mathrm{OC}$ between night and day (the ratio between the two percentages is here 1.72). It may well be that only the difference in levoglucosan carbon to the WIOC between day and night is attributable to further oxidation of levoglucosan during the daytime. 

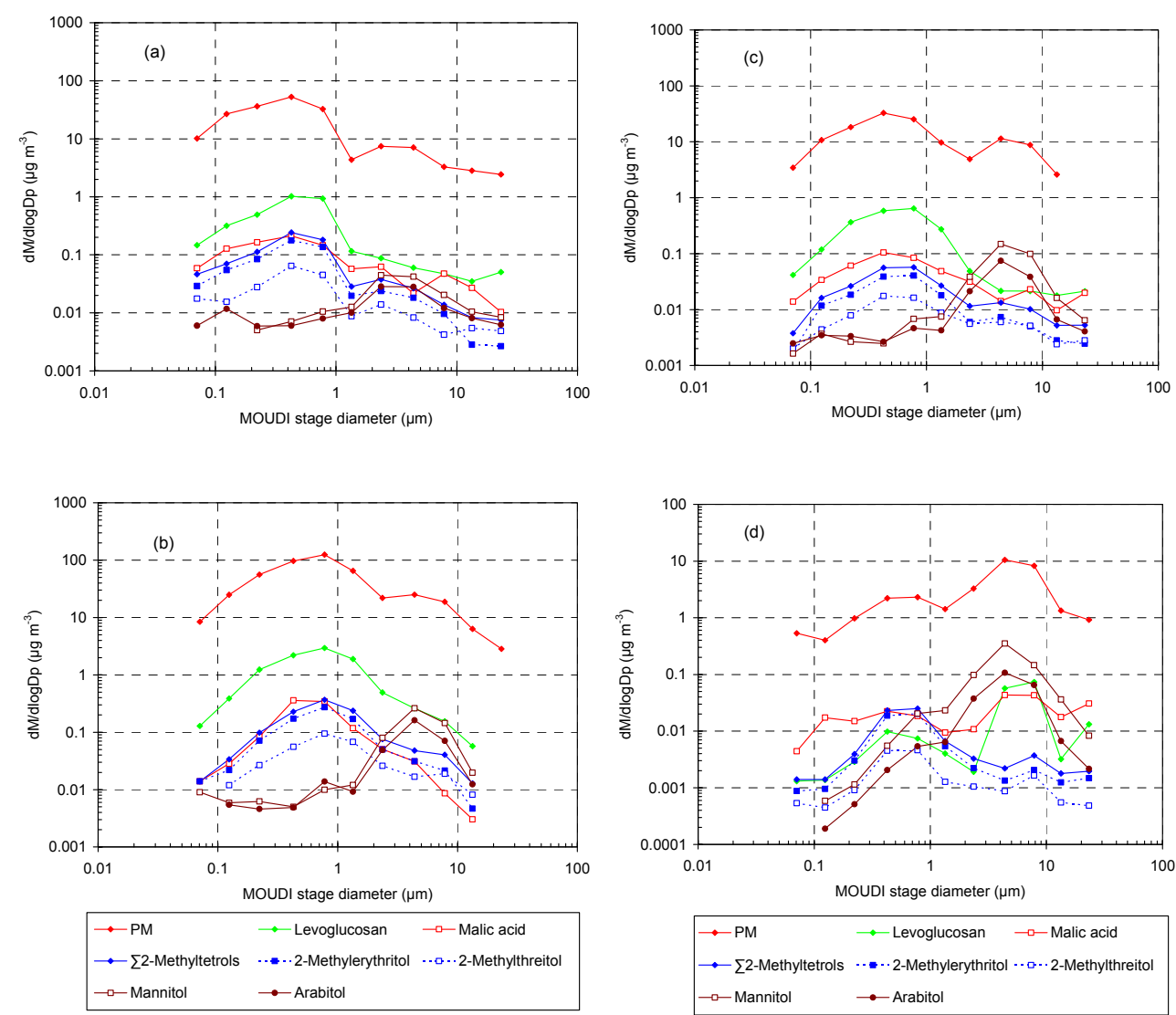

Fig. 4. Mass-size distributions of selected polar organic marker compounds and the PM during the 17 September 2002 day (a) and night (b) of the dry period, a 24-h sampling on 17 October 2002 of the transition period (c), and a 48-h sampling, 10-12 November 2002, of the wet period (d).

Figure $4 a-d$ present typical size distributions of the PM and levoglucosan, as well as of malic acid, the 2methyltetrols, mannitol and arabitol, for the dry, transition, and wet periods of the LBA-SMOCC 2002 campaign. Other indicator compounds such as glucose, fructose, erythritol, galactosan, and mannosan were also detected. However, a detailed examination of those compounds was not performed since they correspond to minor compounds; some of them (galactosan and mannosan) are known to accompany the emission of levoglucosan (Shafizadeh, 1984). It can be seen that the mass size distribution of the PM depends strongly on the period: during the dry period most of the PM is in the fine mode (Fig. 4a and b), while in the transition period a substantial fraction of it is in the coarse mode (Fig. 4c), and in the wet period the coarse mode has become more abundant than the fine one (Fig. 4d). Furthermore, it can be noted that there is a clear difference in the day- and nighttime masssize distributions for the dry period with a more pronounced coarse mode at night than during daytime. Levoglucosan follows quite closely the PM and is mainly associated with the fine size mode, except in the wet period where it peaks in the coarse mode. The latter phenomenon can be explained by a lack of pre-existing fine aerosol surface that is required for condensation of biomass smoke and by the hydrophilic properties of levoglucosan that facilitates its adsorption on the wet surface of coarse biological particles. A similar size distribution as ours for levoglucosan during the dry period was reported by Blazsó et al. (2003) for the LBA-EUSTACH 1999 dry season experiment at the same site.

\subsubsection{Malic acid, 2-methyltetrols and $\mathrm{C}_{5}$-alkene triols}

Figure 5 shows the time series of malic acid, the 2methyltetrols and the $\mathrm{C}_{5}$-alkene triol derivatives of isoprene [sum of 2-methyl-1,3,4-trihydroxy-1-butene (cis and trans) and 3-methyl-2,3,4-trihydroxy-1-butene]. The time series of malic acid and the 2-methyltetrols are quite different from those of levoglucosan (Fig. 3), consistent with different aerosol sources or source processes. It can be seen that the concentrations of both malic acid and the 2-methyltetrols are higher in the dry and transition periods than in the wet period. The mass-size distributions of malic acid (Fig. 4a-d) show that it follows quite closely that of levoglucosan; it is mainly associated with the fine size mode, except in the wet 


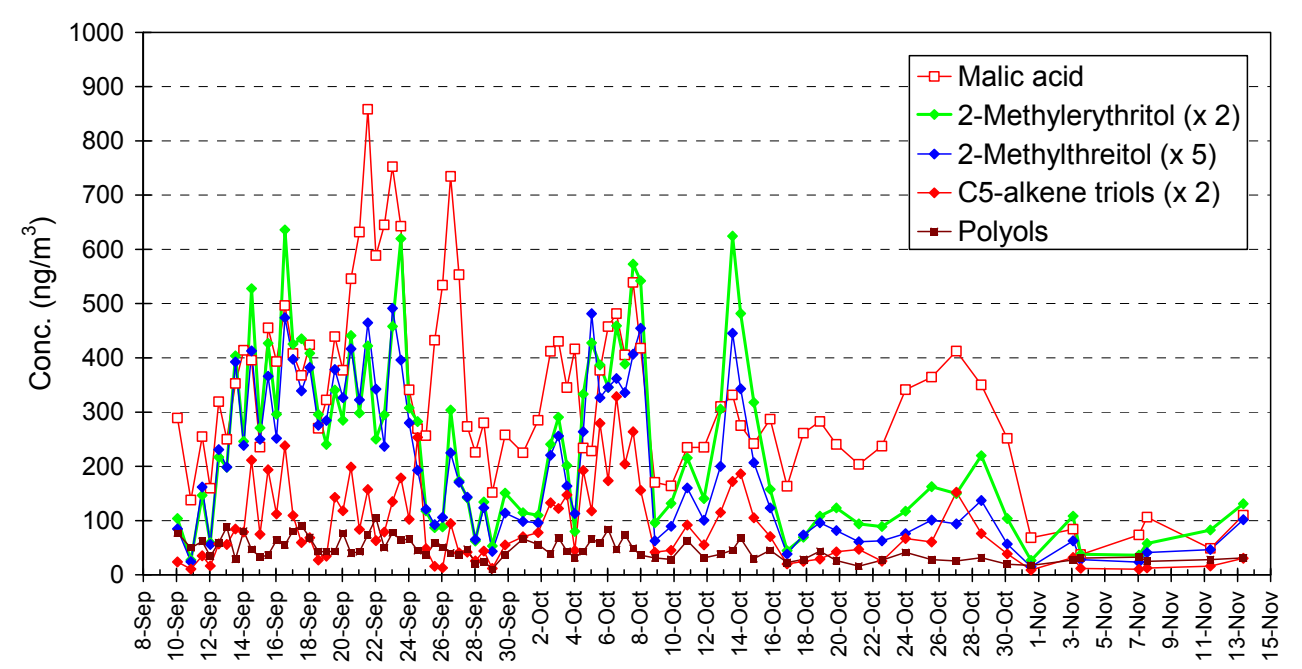

Fig. 5. Time series for malic acid, 2-methyltetrols (2-methylthreitol and 2-methylerythritol), $\mathrm{C}_{5}$-alkene triol derivatives of isoprene (sum of 2-methyl-1,3,4-trihydroxy-1-butene (cis and trans) and 3-methyl-2,3,4-trihydroxy-1-butene) and polyols (sum of arabitol, mannitol, and erythritol) in the fine filters of the HVDS samples.

period where it is also more abundant in the coarse mode. The similar behaviors of levoglucosan and malic acid suggest the same aerosol formation process, namely, condensation of low-volatile organic vapors that are either emitted during deforestation fires by a high temperature process (in the case of levoglucosan) or formed by photooxidation of biogenic emissions and vapors released during the fires (in the case of malic acid). The different size distributions of malic acid and levoglucosan during the wet season, where both compounds are mainly associated with the coarse size mode, can be explained by a lack of fine aerosol surface onto which low-volatile organic vapors can condense. As to the origin of malic acid, it has been proposed that it is formed from $\mathrm{C}_{n}(n \leq 6)$ semivolatile carboxylic acids, i.e., further photooxidation of succinic acid (Kawamura and Gagosian, 1990; Kawamura and Ikushima, 1993), which in the present case can be explained by daytime photooxidation of semivolatile carboxylic acids that are emitted during biomass burning (Kundu et al., 2010). A fairly good correlation was found between the concentrations of malic and succinic acid during the dry and transitions periods $(r=0.76)$, supporting that both tracers have the same aerosol source and are formed through photooxidation of $\mathrm{C}_{n}(n \leq 6)$ semivolatile carboxylic acids. It is noted that an even better correlation $(r=0.92)$ between the concentrations of malic and succinic acid has been reported for $\mathrm{PM}_{2.5}$ aerosols collected from K-puszta, Hungary, during a 2003 summer period (Kourtchev et al., 2009). As can be seen in Fig. 5, malic acid does not reveal a diel variation; this behavior of malic acid has been noted in previous field studies such as, for example, during a 2003 summer campaign in K-puszta, Hungary (Ion et al., 2005), and has been explained by its formation from both anthropogenic and biogenic sources over a relatively long time scale.
It can be seen in Fig. 5 that the 2-methyltetrols, 2methylthreitol and 2-methylerythritol, closely follow each other. The ratio between the threo and erythro isomers was on average 0.30 and a statistically significant correlation was found between them $(r=0.94)$, consistent with their formation through the same aerosol formation process, namely, photooxidation of isoprene. The ratio threolerythro of 0.30 compares well with the ratio of between 0.33 and 0.58 found for aerosol $\left(\mathrm{PM}_{2.5}, \mathrm{PM}_{1}\right.$, or total aerosol) collected at other forested sites (e.g., 0.37, Ion et al., 2005; 0.40, Cahill et al., 2006; 0.48, Kourtchev et al., 2008a; 0.33, Clements and Seinfeld, 2007; 0.58, Xia and Hopke, 2006; 0.41 , Kourtchev et al., 2008b). The higher concentrations of the 2-methyltetrols during the dry and transition periods compared to the wet period can in part be explained by a difference in the acidity of the aerosol. Smog chamber studies with isoprene (Edney et al., 2005; Surratt et al., 2007a, b) as well as field studies (Kourtchev et al., 2008a; Lewandowski et al., 2007) have demonstrated that the formation of 2-methyltetrols is strongly affected by the acidity of the aerosol. It is noted that during the LBA-SMOCC 2002 experiment the mixing ratios of the acidic trace gases $\mathrm{HNO}_{3}$ and $\mathrm{SO}_{2}$ were considerably higher during the dry and transition periods than the wet period, and that the same trends were found for aerosol $\mathrm{NO}_{3}^{-}$and $\mathrm{SO}_{4}^{2-}$ anions showing maxima of $1.25 \mathrm{ppb}$ and $0.6 \mathrm{ppb}$, respectively (Trebs et al., 2004). In addition, the higher concentrations of the 2-methyltetrols during the dry and transition periods compared to the wet period may in part be explained by differences in the emission rate of isoprene, the $\mathrm{NO}_{\mathrm{x}}$ concentration and the removal by wet deposition. As to seasonal variations in the emission rate of isoprene in the Amazon basin, only slightly higher emissions in the dry than in the wet season were measured 
(i.e., at National Forest of the Tapajos mean isoprene mixing ratios were $2.8 \pm 0.9 \mathrm{ppb}, 1.4 \pm 0.5 \mathrm{ppb}$ and $1.9 \pm 1.2 \mathrm{ppb}$ in the dry, transition, and wet periods, respectively, Trostdorf et al., 2004), so that other factors such as the aerosol acidity, the $\mathrm{NO}_{\mathrm{x}}$ concentration and wet deposition mainly determine the concentrations of the 2-methyltetrols. As to seasonal variations in the $\mathrm{NO}_{\mathrm{x}}$ concentration, substantial differences were reported by Trebs et al. (2006), who measured median $\mathrm{NO}_{\mathrm{x}}$ mixing ratios in the dry, transition, and wet periods of $4.6 \mathrm{ppb}, 3.0 \mathrm{ppb}$, and $0.9 \mathrm{ppb}$, respectively. It is very likely that the 2-methyltetrol concentrations were also affected by the $\mathrm{NO}_{\mathrm{x}}$ concentration, since $\mathrm{NO}_{\mathrm{x}}$ is known to play a role in their formation (Sato, 2008; Szmigielski et al., 2010). During the dry period, the 2-methyltetrol concentrations show a clear diel variation with highest concentrations during daytime. This is in accordance to observations made for aerosol $\left(\mathrm{PM}_{1}\right.$ or $\left.\mathrm{PM}_{2.5}\right)$ from other forested sites (Ion et al., 2005; Plewka et al., 2006; Kourtchev et al., 2008a), where a diel pattern was found for the 2-methyltetrol concentrations with maxima during daytime, which is consistent with their fast photochemical formation from locally emitted isoprene. The 2-methyltetrols were poorly correlated with malic acid $(r=0.55)$, as could be expected since they have a different aerosol source. No conclusions could be made regarding diel variations in the 2-methyltetrol concentrations during the transition and wet periods, since there were not sufficient day/night samples taken during these periods. In addition to the 2-methyltetrols, the $\mathrm{C}_{5}$-alkene triols were detected at significant concentrations during the dry and transition periods, and also exhibited higher concentrations during daytime. The latter photooxidation products of isoprene have been reported at high concentrations in $\mathrm{PM}_{1}$ aerosol from a boreal forest site, Hyytiälä, southern Finland, during 2004 and 2005 summer periods (Kourtchev et al., 2005, 2008a), especially during an episode that was characterized by a higher acidity. The percentage concentration ratios $\mathrm{C}_{5}$ alkene triols/2-methyltetrols were $28 \%, 31 \%$, and $20 \%$ for the dry, transition, and wet periods of the LBA-SMOCC campaign, respectively, and are thus higher than the percentage ratios of less than $10 \%$ measured in laboratory isoprene photooxidation experiments performed in the absence of $\mathrm{NO}_{\mathrm{x}}$ (Kleindienst et al., 2009). Possible reasons for this discrepancy are that the $\mathrm{NO}_{\mathrm{x}}$ regimes are different under the ambient conditions and that the RH in the moist tropical atmosphere is much higher (it was, on average, $78 \%$ during the SMOCC campaign) than that employed in the latter laboratory study (i.e., $<3 \%$ ). It is worth noting that during all periods of the LBA-SMOCC 2002 campaign the $\mathrm{NO}_{\mathrm{x}}$ regime cannot be regarded as a low- $\mathrm{NO}_{\mathrm{x}}$ one $(<10 \mathrm{ppt})$ since the median $\mathrm{NO}_{\mathrm{x}}$ mixing ratios in the dry, transition and wet periods were $4.6 \mathrm{ppb}, 3.0 \mathrm{ppb}$ and $0.9 \mathrm{ppb}$, respectively (Trebs et al., 2006). With respect to the effect of the RH, it has been reported in a recent laboratory study in the absence of $\mathrm{NO}_{\mathrm{x}}$ (considered as low- $\mathrm{NO}_{\mathrm{x}}$ ) by Surratt et al. (2010) that the concentration ratio $\mathrm{C}_{5}$-alkene triols/2-methyltetrols is strongly affected by the RH. The mass size distributions of the 2-methyltetrols (Fig. 4a-d) show that they have the same pattern as those of levoglucosan and malic acid, and are mainly associated with the fine size mode during the dry and transition periods. However, it is noted that the mass size distributions of the 2-methyltetrols are distinctly different from those of levoglucosan and malic acid during the wet period, where the 2-methyltetrols remain associated with the fine size mode. The latter behavior of the 2-methyltetrols is consistent with an aerosol formation process that is different from that for levoglucosan and malic acid; in the case of the 2-methyltetrols a heterogeneous process is suggested, while that for levoglucosan and malic acid involves condensation of low-volatile organic vapors onto pre-existing aerosol particles. The $\mathrm{C}_{5}$-alkene triols in the MOUDI sample sets from the dry and transition periods were below the detection limit, but could be measured in the fine size fractions of the wet period MOUDI sample set, where their concentrations were about $20 \%$ of those of the 2-methyltetrols (results not shown).

Both the 2-methyltetrols and $\mathrm{C}_{5}$-alkene triols are isoprene SOA tracers under low- $\mathrm{NO}_{\mathrm{x}}$ conditions (Surratt et al., 2006; Kleindienst et al., 2009); the formation of 2methyltetrols can be explained by acid-catalyzed degradation of $\mathrm{C}_{5}$-trihydroxyhydroperoxides (Kleindienst et al., 2009) and/or $\mathrm{C}_{5}$-epoxydiols (Paulot et al., 2009; Surratt et al., 2010), while that of the $\mathrm{C}_{5}$-alkene triols can be explained by acid-catalyzed degradation of $\mathrm{C}_{5}$-epoxydiols (Wang et al., 2005; Surratt et al., 2010). It is noted that during the dry and transition periods of the LBA-SMOCC campaign the $\mathrm{NO}_{\mathrm{x}}$ mixing ratios were in the $1-5 \mathrm{ppb}$ range (Trebs et al., 2006), which can be considered as an intermediate $\mathrm{NO}_{\mathrm{x}}$ regime, suggesting that the $\mathrm{C}_{5}$-alkene triols may not be as unique to low- $\mathrm{NO}_{x}$ conditions as originally thought (Surratt et al., 2006). It can be seen that the size distribution observed during the wet season for the 2-methyltetrols (Fig. 4d) differs from that of other polar compounds that partition from the gas to the particle phase such as levoglucosan and malic acid. A possible explanation is that only the freshly generated fine particles are sufficiently acidic to generate the 2methyltetrols from their gas-phase precursors through acidcatalyzed reactions. In this context, it is worth noting that both the 2-methyltetrols (Fig. 4a-d) and inorganic sulfate (Fig. 4 in Fuzzi et al., 2007) are mainly associated with the fine size mode.

\subsubsection{Arabitol, mannitol, and erythritol}

Arabitol, mannitol, and erythritol are marker compounds for airborne fungal spores (Lewis and Smith, 1967; Bieleski, 1982) that are expected to be mainly associated with the coarse aerosol (Matthias-Maser and Jaenicke, 1995; Bauer et al., 2002a, b). However, together with fungal spores also fragments may be released from moldy surfaces (Górny et al., 2002), explaining why these polyols are also present in 
the $\mathrm{PM}_{2.5}$ HVDS samples, as has been reported in previous studies (Graham et al., 2003; Yttri et al., 2007). The time series for the polyols (arabitol, mannitol, and erythritol) (Fig. 5) reveals little variation throughout the dry, transition, and wet periods of the LBA-SMOCC 2002 campaign, as could be expected for these compounds since the humid tropical rain forest remains active throughout the whole year in producing fungal material. In addition, no clear day/night variations could be noted for their $\mathrm{PM}_{2.5}$ concentrations (Fig. 5).

The mass size distributions of arabitol and mannitol (Fig. 4a-d) show that they have similar patterns and are mainly associated with the coarse mode. The day- and nighttime data for samplings in the dry period (Fig. 4a and b) show that the concentrations of arabitol and mannitol are about two times higher at night than during daytime, consistent with observations made by Graham et al. (2003) during the LBACLAIRE 2001 wet season campaign on the coarse size fractions of HVDS samples. These day/night differences have been explained by a nocturnal increase in wet spore discharging fungi such as Ascomycota and Basidiomycota (Elbert et al., 2007); an alternative explanation for this phenomenon, however, is trapping of the released fungal material under the shallow nocturnal boundary layer. The mass size distributions of arabitol and mannitol for the 48-h sampling during the wet period (Fig. 4d) clearly show a tail into the fine size mode, suggesting an enhanced release of fungal fragments from the biota during this period compared to the transition and dry periods. Size-fractionated aerosol data revealing similar patterns for arabitol and/or mannitol were reported for samples from a rural meadow site in Melpitz, Germany (Carvalho et al., 2003) and from urban sites in Norway (Yttri et al., 2007), where arabitol and/or mannitol clearly peaked in the coarse mode between 1.3 and $4.2 \mu \mathrm{m}$, which is the size range for spores of typical airborne fungal strains (Bauer et al., 2002b).

\section{Conclusions}

Sources, source processes, time series, diel variations, and size distributions of organic marker compounds were investigated for carbonaceous aerosols that were collected during the LBA-SMOCC field experiment, conducted in Rondônia, Brazil, in 2002 during dry, intermediate, and wet periods. During all three periods levoglucosan was found to be the most dominant organic species in $\mathrm{PM}_{2.5}$ samples and reached up to $7.5 \mu \mathrm{g} \mathrm{m}^{-3}$ during the dry period, which was characterized by intense deforestation fires. During the dry period, levoglucosan exhibited diel variations with a nighttime prevalence. In the size-segregated samples, levoglucosan was found to be closely associated with the PM and mainly found in the fine mode, except during the wet period, where it peaked in the coarse mode. Isoprene oxidation products were found to be important species in $\mathrm{PM}_{2.5}$ at this pas- ture site (on average $250 \mathrm{ng} \mathrm{m}^{-3}$ during the dry period versus $157 \mathrm{ng} \mathrm{m}^{-3}$ during the transition period and $52 \mathrm{ng} \mathrm{m}^{-3}$ during the wet period) and the seasonal differences were mainly attributed to differences in the acidity of the aerosols, the $\mathrm{NO}_{\mathrm{x}}$ concentration and wet deposition. In addition, during the dry period clear diel variations were observed for the isoprene oxidation products with a daytime prevalence, which is consistent with their fast formation from locally emitted isoprene. In size-segregated samples, malic acid and the 2methyltetrols exhibited a different distribution pattern. While the 2-methyltetrols were found to be mainly associated with the fine mode during all periods, malic acid was found to be prevalent in the fine mode only during the dry and transition periods and in the coarse mode during the wet period, indicating that the aerosol formation processes for those species are distinctly different. The unique behavior of the 2methyltetrols is explained by heterogeneous chemistry, likely involving acid-catalyzed degradation of their gas-phase precursors onto an acidic particle surface. Marker compounds for airborne fungi included arabitol, mannitol, and erythritol. The sum of these polyols in $\mathrm{PM}_{2.5}$ during the dry, transition, and wet periods was, on average, $54 \mathrm{ng} \mathrm{m}^{-3}, 34 \mathrm{ng} \mathrm{m}^{-3}$, and $27 \mathrm{ng} \mathrm{m}^{-3}$, respectively and revealed minor day/night variation. The mass size distributions of arabitol and mannitol during all periods showed similar patterns and an association with the coarse mode, which is consistent with their primary source origin.

Acknowledgements. This work was carried out within the framework of the Smoke, Aerosols, Clouds, Rainfall, and Climate (SMOCC) project, a European contribution to the Large-Scale Biosphere-Atmosphere Experiment in Amazonia (LBA). It was financially supported by the Environmental and Climate Program of the European Commission (contract No. EVK2-CT-2001-00110 SMOCC), the Max Planck Society (MPG), the Belgian Federal Science Policy Office through the project "Characterization and sources of carbonaceous atmospheric aerosols" (contracts EV/06/11B and EV/02/11A), a postdoctoral visiting fellowship to V. Pashynska within the programme to promote collaboration between researchers of Central and Eastern Europe and of Belgium, the Fund for Scientific Research - Flanders, the Fundação de Amparo à Pesquisa do Estado de São Paulo, and the Conselho Nacional de Desenvolvimento Científico (Instituto do Milênio LBA). We thank all members of the LBA-SMOCC and LBA-RACCI Science Teams for their support during the field campaign, especially A. C. Ribeiro, M. A. L. Moura and J. von Jouanne.

Edited by: A. Chen

\section{References}

Andreae, M. O., Artaxo, P., Brandão, C., Carswell, F. E., Ciccioli, P., da Costa, A. L., Culf, A. D., Esteves, J. L., Gash, J. H. C., Grace, J., Kabat, P., Lelieveld, J., Malhi, Y., Manzi, A. O., Meixner, F. X., Nobre, A. D., Ruivo, M. d. L. P., Silva-Dias, M. A., Stefani, P., Valentini, R., von Jouanne, J., and Waterloo, M. J.: Biogeochemical cycling of carbon, water, energy, trace gases, 
and aerosols in Amazonia: The LBA-EUSTACH experiments, J. Geophys. Res., 107, 8066, doi:10.1029/2001JD000524, 2002.

Andreae, M. O., Rosenfeld, D., Artaxo, P., Costa, A. A., Frank, G. P., Longo, K. M., and Silva-Dias, M. A. F.: Smoking rain clouds over the Amazon, Science, 303, 1337-1342, 2004.

Baker, H. G., Baker, I., and Hodges, S. A.: Sugar composition of nectars and fruits consumed by birds and bats in the tropics and subtropics, Biotropica, 30, 559-586, 1998.

Bartolozzi, F., Bertazza, G., Bassi, D., and Cristofori, G.: Simultaneous determination of soluble sugars and organic acids as their trimethylsilyl derivatives in apricot fruits by gas-liquid chromatography, J. Chromatogr. A, 758, 99-107, 1997.

Bauer, H., Kasper-Giebl, A., Löflund, M., Giebl, H., Hitzenberger, R., Zibuschka, F., and Puxbaum, H.: The contribution of bacteria and fungal spores to the organic carbon content of cloud water, precipitation and aerosols, Atmos. Res., 64, 109-119, 2002a.

Bauer, H., Kasper-Giebl, A., Zibuschka, F., Hitzenberger, R., Kraus, G. F., and Puxbaum, H.: Determination of the carbon content of airborne fungal spores, Anal. Chem., 74, 91-95, 2002 b.

Bieleski, R. L.: Sugar alcohols, in: Encyclopedia of Plant Physiology, volume 13A, Plant Carbohydrates, volume I, Intracellular Carbohydrates, edited by: Loewis, A. and Tanner, W., SpringerVerlag, Berlin, 158-170, 1982.

Birch, M. E. and Cary, R. A.: Elemental carbon-based method for monitoring occupational exposures to particulate diesel exhaust, Aerosol Sci. Technol., 25, 221-241, 1996.

Blazsó, M., Janitsek, S., Gelencsér, A., Artaxo, P., Graham, B., and Andreae, M. O.: Study of tropical organic aerosol by thermally assisted alkylation-gas chromatography mass spectrometry, J. Anal. Appl. Pyrol., 68/69, 351-369, 2003.

Böge, O., Miao, Y., Plewka, A., and Herrmann, H.: Formation of secondary organic particle phase compounds from isoprene gasphase oxidation products: an aerosol chamber and field study, Atmos. Environ., 40, 2501-2509, 2006.

Cahill, T. M., Seaman, V. Y., Charles, M. J., Holzinger, R., and Goldstein, A. H.: Secondary organic aerosols formed from oxidation of biogenic volatile organic compounds in the Sierra Nevada Mountains of California, J. Geophys. Res., 111, D16312, doi:10.1029/2006JD007178, 2006.

Carvalho, A., Pio, C., and Santos, C.: Water-soluble hydroxylated organic compounds in German and Finnish aerosols, Atmos. Environ., 37, 1775-1783, 2003.

Claeys, M., Graham, B., Vas, G., Wang, W., Vermeylen, R., Pashynska, V., Cafmeyer, J., Guyon, P., Andreae, M. O., Artaxo, P., and Maenhaut, W.: Formation of secondary organic aerosols through photooxidation of isoprene, Science, 303, 1173-1176, 2004.

Clements, A. and Seinfeld, J. H.: Detection and quantification of 2-methyltetrols in ambient aerosol in the southeastern United States, Atmos. Environ., 41, 1825-1830, 2007.

Decesari, S., Fuzzi, S., Facchini, M. C., Mircea, M., Emblico, L., Cavalli, F., Maenhaut, W., Chi, X., Schkolnik, G., Falkovich, A., Rudich, Y., Claeys, M., Pashynska, V., Vas, G., Kourtchev, I., Vermeylen, R., Hoffer, A., Andreae, M. O., Tagliavini, E., Moretti, F., and Artaxo, P.: Characterization of the organic composition of aerosols from Rondônia, Brazil, during the LBASMOCC 2002 experiment and its representation through model compounds, Atmos. Chem. Phys., 6, 375-402, doi:10.5194/acp6-375-2006, 2006.

Edney, E. O., Kleindienst, T. E., Jaoui, M., Lewandowski, M., Of- fenberg, J. H., Wang, W., and Claeys, M.: Formation of 2-methyl tetrols and 2-methylglyceric acid in secondary organic aerosol from laboratory irradiated isoprene/ $\mathrm{NO}_{\mathrm{x}} / \mathrm{SO}_{2}$ /air mixtures and their detection in ambient $\mathrm{PM}_{2.5}$ samples collected in the eastern United States, Atmos. Environ., 39, 5281-5289, 2005.

Elbert, W., Taylor, P. E., Andreae, M. O., and Pöschl, U.: Contribution of fungi to primary biogenic aerosols in the atmosphere: wet and dry discharged spores, carbohydrates, and inorganic ions, Atmos. Chem. Phys., 7, 4569-4588, doi:10.5194/acp-7-4569-2007, 2007.

Facchini, M. C., Mircea, M., Fuzzi, S., and Charlson, R. J.: Cloud albedo enhancement by surface-active organic solutes in growing droplets, Nature, 401, 257-259, 1999.

Falkovich, A. H., Graber, E. R., Schkolnik, G., Rudich, Y., Maenhaut, W., and Artaxo, P.: Low molecular weight organic acids in aerosol particles from Rondônia, Brazil, during the biomassburning, transition and wet periods, Atmos. Chem. Phys., 5, 781797, doi:10.5194/acp-5-781-2005, 2005.

Fisch, G., Tota, J., Machado, L. A. T., Dias, M., Lyra, R. F. D., Nobre, C. A., Dolman, A. J., and Gash, J. H. C.: The convective boundary layer over pasture and forest in Amazonia, Theor. Appl. Climatol., 78, 47-59, 2004.

Fuzzi, S., Decesari, S., Facchini, M. C., Cavalli, F., Emblico, L., Mircea, M., Andreae, M. O., Trebs, I., Hoffer, A., Guyon, P., Artaxo, P., Rizzo, L. V., Lara, L. L., Pauliquevis, T., Maenhaut, W., Raes, N., Chi, X., Mayol-Bracero, O. L., Soto-García, L., Claeys, M., Kourtchev, I., Rissler, J., Swietlicki, E., Tagliavini, E., Schkolnik, G., Falkovich, A. H., Rudich, Y., Fisch G., and Gatti, L. V.: Overview of the inorganic and organic composition of size-segregated aerosol in Rondônia, Brazil, from the biomass burning period to the onset of the wet season, J. Geophys. Res., 112, D01201, doi:10.1029/2005JD006741, 2007.

Gao, S., Hegg, D. A., Hobbs, P. V., Kirchstetter, T. W., Magi, B. I., and Sadilek, M.: Water-soluble organic components in aerosols associated with savanna fires in southern Africa: identification, evolution, and distribution, J. Geophys. Res., 108, 8491, doi:10.1029/2002JD002324, 2003

Górny, R. L., Reponen, T., Willeke, K., Robine, E., Boissier, M., and Grinshpun, S. A.: Fungal fragments as indoor biocontaminants, Appl. Environ. Microbiol., 68, 3522-3531, 2002.

Graham, B., Mayol-Bracero, O. L., Guyon, P., Roberts, G. C., Decesari, S., Facchini, M. C., Artaxo, P., Maenhaut, W., Köll, P., and Andreae, M. O.: Water-soluble organic compounds in biomass burning aerosols over Amazonia: 1. Characterization by NMR and GC-MS, J. Geophys. Res., 107, 8047, doi:10.1029/2001JD000336, 2002.

Graham, B., Guyon, P., Taylor, P. E., Artaxo, P., Maenhaut, W., Glovsky, M. M., Flagan, R. C., and Andreae, M. O.: Organic compounds present in the natural Amazonian aerosol: characterization by gas chromatography-mass spectrometry, J. Geophys. Res., 108, 4766, doi:10.1029/2003JD003990, 2003.

Hennigan, C. J., Sullivan, A. P., Collett, J. L., and Robinson, A. L.: Levoglucosan stability in biomass burning particles exposed to hydroxyl radicals, Geophys. Res. Lett., 37, L09806, doi:10.1029/2010GL043088, 2010

Hoffmann, D., Tilgner, A., Iinuma, Y., and Herrmann, H.: Atmospheric stability of levoglucosan: A detailed laboratory and modeling study, Environ. Sci. Technol., 44, 694-699, 2010.

Ion, A. C., Vermeylen, R., Kourtchev, I., Cafmeyer, J., Chi, X., Ge- 
lencsér, A., Maenhaut, W., and Claeys, M.: Polar organic compounds in rural $\mathrm{PM}_{2.5}$ aerosols from K-puszta, Hungary, during a 2003 summer field campaign: Sources and diel variations, Atmos. Chem. Phys., 5, 1805-1814, doi:10.5194/acp-5-1805-2005, 2005.

Kawamura, K. and Gagosian, R. B.: Mid-chain ketocarboxylic acids in the remote marine atmosphere: Distribution patterns and possible formation mechanisms, J. Atmos. Chem., 11, 107-122, 1993.

Kawamura, K. and Ikushima, K.: Seasonal changes in the distribution of dicarboxylic acids in the urban atmosphere, Environ. Sci. Technol., 27, 2227-2235, 1993.

Kleindienst, T. E., Lewandowski, M., Offenberg, J. H., Jaoui, M., and Edney, E. O.: The formation of secondary organic aerosol from the isoprene $+\mathrm{OH}$ reaction in the absence of $\mathrm{NO}_{\mathrm{x}}$, Atmos. Chem. Phys., 9, 6541-6558, doi:10.5194/acp-9-6541-2009, 2009.

Kourtchev, I., Ruuskanen, T., Maenhaut, W., Kulmala, M., and Claeys, M.: Observation of 2-methyltetrols and related photo-oxidation products of isoprene in boreal forest aerosols from Hyytiälä, Finland, Atmos. Chem. Phys., 5, 2761-2770, doi:10.5194/acp-5-2761-2005, 2005.

Kourtchev, I., Ruuskanen, T. M., Keronen, P., Sogacheva, L., Dal Maso, M., Reissell, A., Chi, X., Vermeylen, R., Kulmala, M., Maenhaut, W., and Claeys, M.: Determination of isoprene and $\alpha-/ \beta$-pinene oxidation products in boreal forest aerosols from Hyytiälä, Finland: diel variations and possible link with particle formation events, Plant Biology, 10, 138-149, 2008a.

Kourtchev, I., Warnke, J., Maenhaut, W., Hoffmann, T., and Claeys, M.: Polar organic marker compounds in PM2.5 aerosol from a mixed forest site in western Germany, Chemosphere, 73, 13091314, 2008b.

Kourtchev, I., Copolovici, L., Claeys, M., and Maenhaut, W.: Characterization of aerosols at a forested site in central Europe, Environ. Sci. Technol., 43, 4665-4671, 2009.

Kubátová, A., Vermeylen, R., Claeys, M., Cafmeyer, J., Maenhaut, W., Roberts, G., and Artaxo, P.: Carbonaceous aerosol characterization in the Amazon basin, Brasil: novel dicarboxylic acids and related compounds, Atmos. Environ., 34, 5037-5051, 2000.

Kundu, S., Kawamura, K., Andreae, T. W., Hoffer, A., and Andreae, M. O.: Molecular distributions of dicarboxylic acids, ketocarboxylic acids and $\alpha$-dicarbonyls in biomass burning aerosols: implications for photochemical production and degradation in smoke layers, Atmos. Chem. Phys., 10, 2209-2225, doi:10.5194/acp-10-2209-2010, 2010.

Lewandowski, M., Jaoui, M., Kleindienst, T. E., Offenberg, J. H., and Edney, E. O.: Composition of $\mathrm{PM}_{2.5}$ during the summer of 2003 in Research Triangle Park, North Carolina, Atmos. Environ., 41, 4073-4083, 2007.

Lewis, D. H. and Smith, D. C.: Sugar alcohols (polyols) in fungi and green plants: 1. Distribution, physiology and metabolism, New Phytol., 66, 143-184, 1967.

Limbeck, A. and Puxbaum, H.: Organic acids in continental background aerosols, Atmos. Environ., 33, 1847-1852, 1999.

Matthias-Maser, S. and Jaenicke, R.: Size distribution of primary biological aerosol particles with radii $\geq 0.2 \mu \mathrm{m}$. Atmos. Res., 39, 279-286, 1995.

Mayol-Bracero, O. L., Guyon, P., Graham, B., Roberts, G. C., Andreae, M. O., Decesari, S., Facchini, M. C., Fuzzi, S., and Ar- taxo, P.: Water-soluble organic compounds in biomass burning aerosols over Amazonia: 2. Apportionment of the chemical composition and importance of the polyacidic fraction, J. Geophys. Res., 107, 8091, doi:10.1029/2001JD000522, 2002.

Mircea, M., Facchini, M. C., Decesari, S., Cavalli, F., Emblico, L., Fuzzi, S., Vestin, A., Rissler, J., Swietlicki, E., Frank, G., Andreae, M. O., Maenhaut, W., Rudich, Y., and Artaxo, P.: Importance of the organic aerosol fraction for modeling aerosol hygroscopic growth and activation: a case study in the Amazon Basin, Environ. Sci. Technol., 5, 3111-3126, 2005.

Mochida, M. and Kawamura, K.: Hygroscopic properties of levoglucosan and related organic compounds characteristic to biomass burning aerosol particles, J. Geophys. Res., 109, D21202, doi:10.1029/2004JD004962, 2004.

Nolte, C., Schauer, J. J., Cass, G. R., and Simoneit, B. R. T.: Highly polar organic compounds present in wood smoke and in the ambient atmosphere, Environ. Sci. Technol., 35, 1912-1919, 2001.

Novakov, T. and Penner, J. E.: Large contribution of organic aerosols to cloud-condensation-nuclei, Nature, 365, 823-826, 1993.

Novakov, T. and Corrigan, C. E.: Cloud condensation nucleus activity of the organic component of biomass smoke particles, Geophys. Res. Lett., 23, 2141-2144, 1996.

Pacini, E.: From anther and pollen ripening to pollen presentation, Plant Sys. Evol., 222, 19-43, 2000.

Pashynska, V., Vermeylen, R., Vas, G., Maenhaut, W., and Claeys, M.: Development of a gas chromatography/ion trap mass spectrometry method for determination of levoglucosan and saccharidic compounds in atmospheric aerosols: Application to urban aerosols, J. Mass Spectrom., 37, 1249-1527, 2002.

Paulot, F., Crounse, J. D., Kjaergaard, H. G., Kürten, A., St. Clair, J. M., Seinfeld, J. H., and Wennberg, P. O.: Unexpected epoxide formation in the gas-phase photooxidation of isoprene, Science, 325, 730-733, 2009.

Plewka, A., Gnauk, T., Brüggeman, E., and Herrmann, H.: Biogenic contribution to the chemical composition of airborne particles in a coniferous forest in Germany, Atmos. Environ., 40, S103S115, 2006.

Rissler, J., Vestin, A., Swietlicki, E., Fisch, G., Zhou, J., Artaxo, P., and Andreae, M. O.: Size distribution and hygroscopic properties of aerosol particles from dry-season biomass burning in Amazonia, Atmos. Chem. Phys., 6, 471-491, doi:10.5194/acp6-471-2006, 2006.

Roberts, G. C., Artaxo, P., Zhou, J., Swietlicki, E., and Andreae, M. O.: Activity of CCN spectra on chemical and physical properties of aerosol: a case study from the Amazon basin, J. Geophys. Res., 107, 8070, doi:10.1029/2001JD000583, 2002.

Rogge, W. F., Hildemann, L. M., Mazurek, M. A., Cass, G. R., and Simoneit, B. R. T.: Quantification of urban organic aerosols at a molecular level: identification, abundance and seasonal variation, Atmos. Environ., 27, 1309-1330, 1993.

Sato, K.: Detection of nitrooxypolyols in secondary organic aerosol formed from the photooxidation of conjugated dienes under high-NO $\mathrm{NO}_{\mathrm{x}}$ conditions, Atmos. Environ., 42, 6851-6861, 2008.

Shafizadeh, F.: The chemistry of pyrolysis and combustion, in: Chemistry of Solid Wood, Rowell, R. (Ed), Advances in Chemistry Series 207, American Chemical Society, Washington DC, 489-529, 1984.

Solomon, P. A., Moyers, J. L., and Fletcher, R. A.: High-volume 
dichotomous virtual impactor for the fractionation and collection of particles according to aerodynamic size, Aerosol Sci. Technol., 2, 455-464, 1983.

Schkolnik, G., Falkovich, A. H., Rudich, Y., Maenhaut, W., and Artaxo, P.: New analytical method for the determination of levoglucosan, polyhydroxy compounds, and 2-methylerythritol and its application to smoke and rainwater samples, Environ. Sci. Technol., 39, 2744-2752, 2005.

Shulman, M. L., Jacobson, M. C., Charlson, R. J., Synovec, R. E., and Young, T. E.: Dissolution behavior and surface tension effects of organic compounds in nucleating cloud droplets, Geophys. Res. Lett., 23, 277-280, 1996.

Simoneit, B. R. T., Schauer, J. J., Nolte, C. G., Oros, D. R., Elias, V. O., Fraser, M. P., Rogge, W. F., and Cass, G. R.: Levoglucosan, a tracer for cellulose in biomass burning and atmospheric particles, Atmos. Environ., 33, 173-182, 1999.

Simoneit, B. R. T.: Biomass burning - a review of organic tracers for smoke from incomplete combustion, Appl. Geochem., 17, 129-162, 2002.

Surratt, J. D., Murphy, S. M., Kroll, J. H., Ng, N. L., Hildebrandt, L., Sorooshian, A., Szmigielski, R., Vermeylen, R., Maenhaut, W., Claeys, M., Flagan, R. C., and Seinfeld, J. H.: Chemical composition of secondary organic aerosol formed from the photooxidation of isoprene, J. Phys. Chem. A, 110, 9665-9690, 2006.

Surratt, J. D., Kroll, J. H., Kleindienst, T. E., Edney, E. O., Claeys, M., Sorooshian, A., Ng, N. L., Offenberg, J. H., Lewandowski, M., Jaoui, M., Flagan, R. C., and Seinfeld, J. H.: Evidence for organosulfates in secondary organic aerosol, Environ. Sci. Technol., 41, 517-527, 2007a.

Surratt, J. D., Lewandowski, M., Offenberg, J. H., Jaoui, M., Kleindienst, T. E., Edney, E. O., and Seinfeld, J. H.: Effect of acidity on secondary organic aerosol formation from isoprene, Environ. Sci. Technol., 41, 5363-5369, 2007b.

Surratt, J. D., Chan, A. W. H., Eddingsaas, N. C., Chan M. N., Loza, C. L., Kwan, A. J., Hersey, S. P., Flagan, R. C., Wennberg, P. O., and Seinfeld, J. H., Reactive intermediates revealed in secondary organic aerosol formation from isoprene, Proc. Natl. Acad. Sci. USA, 107, 6640-6645, 2010.

Szmigielski, R., Dommen, J., Metzger, A., Maenhaut, W., Baltensperger, U., and Claeys, M.: The acid effect in the formation of 2-methyltetrols from the photooxidation of isoprene in the presence of $\mathrm{NO}_{\mathrm{x}}$, Atmos. Res., doi:10.1016/j.atmosres.2010.02.012, in press, 2010.
Trebs, I., Meixner, F. X., Slanina, J., Otjes, R., Jongejan, P., and Andreae, M. O.: Real-time measurements of ammonia, acidic trace gases and water-soluble inorganic aerosol species at a rural site in the Amazon Basin, Atmos. Chem. Phys., 4, 967-987, doi:10.5194/acp-4-967-2004, 2004.

Trebs, I., Lara, L. L., Zeri, L. M. M., Gatti, L. V., Artaxo, P., Dlugi, R., Slanina, J., Andreae, M. O., and Meixner, F. X.: Dry and wet deposition of inorganic nitrogen compounds to a tropical pasture site (Rondônia, Brazil), Atmos. Chem. Phys., 6, 447-469, doi:10.5194/acp-6-447-2006, 2006.

Trostdorf, C. R., Gatti, L. V., Yamazaki, A., Potosnak, M. J., Guenther, A., Martins, W. C., and Munger, J. W.: Seasonal cycles of isoprene concentrations in the Amazonian rainforest, Atmos. Chem. Phys. Discuss., 4, 1291-1310, doi:10.5194/acpd-4-12912004, 2004.

Viana, M., Chi, X., Maenhaut, W., Querol, X., Alastuey, A., Mikuška, P., and Večeřa, Z.: Organic and elemental carbon concentrations in carbonaceous aerosols during summer and winter sampling campaigns in Barcelona, Spain, Atmos. Environ., 40, 2180-2193, 2006.

Wang, W., Kourtchev, I., Graham, B., Cafmeyer, J., Maenhaut, W., and Claeys, M.: Characterization of oxygenated derivatives of isoprene related to 2-methyltetrols in Amazonian aerosols using trimethylsilylation and gas chromatography/ion trap mass spectrometry, Rapid Commun. Mass Spectrom., 19, 1343-1351, 2005.

Xia, X. and Hopke, P. K.: Seasonal variation of 2-methyltetrols in ambient air samples, Environ. Sci. Technol., 40, 6934-6937, 2006.

Yttri, K. E., Dye, C., and Kiss, G.: Ambient aerosol concentrations of sugars and sugar-alcohols at four different sites in Norway, Atmos. Chem. Phys., 7, 4267-4279, doi:10.5194/acp-7-4267-2007, 2007.

Zdráhal, Z., Oliveira, J., Vermeylen, R., Claeys, M., and Maenhaut, W.: Improved method for quantifying levoglucosan and related monosaccharide anhydrides in atmospheric aerosols and application to samples from urban and tropical locations, Environ. Sci Technol., 36, 747-753, 2002. 